\title{
Molecular assessment of calcium-sensing receptor gene polymorphism rs1801725 in Iraqi women with osteoporosis
}

\begin{abstract}
Adnan F. Al-Azzawie*
Department of Biology, College of Science, University of Tikrit, Tikrit, Iraq

Received:

April 22, 2020

Accepted:

February 28, 2021

Online First:

April 02, 2021

Published:

July 07, 2021

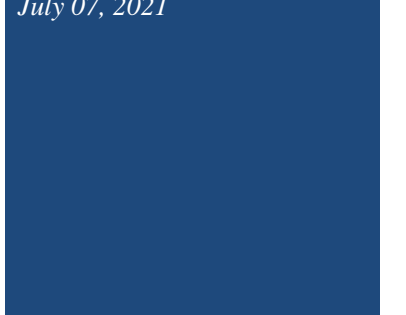

Abstract

Calcium-sensing receptor (CaSR) gene polymorphism A986S (rs1801725) is a genetic factor of the calcium homeostasis and susceptibility of osteoporosis. Although, its role in premenopausal and postmenopausal women with osteoporosis is yet to be investigated. Therefore, this study was conducted to assess the CaSR gene polymorphism A986S and evaluate its correlation with biochemical parameters in premenopausal and postmenopausal Iraqi women with osteoporosis. Blood samples were obtained from 100 women (53 premenopausal and 47 postmenopausal) diagnosed with osteoporosis by specialist physicians and 70 healthy women of the same age as the control group. Serum calcium and phosphorus concentrations were estimated. Genomic DNA was extracted from the whole blood and used for polymerase chain reaction-restriction fragment length polymorphism (PCR-RFLP) analysis to detect CaSR A986S polymorphism. The results obtained showed that calcium and phosphorus levels were significantly lower ( $\mathrm{p}$ value $<0.01$ ) in the osteoporosis women compared with healthy groups. Frequencies of T allele and TT genotype were significantly higher ( $\mathrm{p}$ value $<0.01$ ) in the osteoporosis patients compared with controls, while there were no significant differences in the frequencies of the patient group. Conversely, there were no differences in the calcium and phosphorus levels and there was the presence of T allele of the CaSR A986S genotypes. Thus, our finding revealed that the CaSR polymorphism A986S was one of the genetic susceptibility factors for the premenopausal and postmenopausal in Iraqi women with osteoporosis and had little effects on mineral levels.
\end{abstract}

Keywords: CaSR gene polymorphism A986S, Osteoporosis, Iraqi Women

\section{How to cite this:}

Adnan F. Al-Azzawie, 2021. Molecular assessment of calcium-sensing receptor gene polymorphism rs1801725 in Iraqi women with osteoporosis. Asian J. Agric. Biol. 2021(3): 202004252. DOI: https://doi.org/10.35495/ajab.2020.04.252

*Corresponding author email: adnanmolecular1@gmail.com

This is an Open Access article distributed under the terms of the Creative Commons Attribution 3.0 License. (https://creativecommons.org/licenses/by/3.0), which permits unrestricted use, distribution, and reproduction in any medium, provided the original work is properly cited.

\section{Introduction}

Osteoporosis is a disease accompanied by decreasing bone mass, defects in the microarchitecture of the bone tissue and a raised risk of fragility fractures (Mondockova et al., 2018). It causes 8.9 million fractures each year worldwide (Pouresmaeili et al., 2018). The disease is relatively common in women, especially in post-menopause. About one-third of women over fifty years of age suffer from fragility fractures (Zhu et al., 2017). The relationship between genetic and environmental aspects is central to the 
etiology of osteoporosis (Kanwar et al., 2014). The environmental risk factors such as weak calcium intake, exercise, body mass index, menopause and smoking play a central role in osteoporosis development (Moura et al., 2014; Sassi et al., 2015). Also, the genetic aspect has a strong effect on bone formation and several important genes correlated with bone mineral density (Young et al., 2003). The single nucleotide polymorphism (SNP) is the most significant genetic factors examined in association researches (Hosseinpanah et al., 2014). SNP plays an active role in the development of osteoporosis (AlAzzawie et al., 2020) and some SNPs in candidate osteoporosis genes involved in bone physiology ( Boroňová et al., 2014).

The human chromosomal region 3q13.3-21 contains CaSR gene (Tang et al., 2014). This gene contains about 24000 genetic variants including germline and somatic mutations as well as SNPs (Masvidal et al., 2017). Clinically, mutations of the CaSR gene result in either hypercalcemia (if the receptor is inactivated) leading to hypocalciuric hypercalcemia in the family. Alternatively, it can also lead to hypocalcemia when the receptor is stimulated to yield a hypersensitive receptor that results in autosomal-dominant hypocalcemia (Yan et al., 2015; Rasmussen et al., 2018). Recent studies have revealed a correlation between CaSR gene SNPs and serum calcium levels (Majid et al., 2015). The exon 7 of CaSR gene comprises three SNPs which include Ala986Ser (rs1801725, A986S, base change 2956G >T), Gln1011Glu (Q1011E, base change 3031C > G, rs 1801726) and Arg990Gly (rs1042636, R990G, base change 2968A > G) (Di Nisio et al., 2018). From these SNPs, the A986S (2956G > T) induces a shift in amino acid from alanine (A) to serine (S), and $\mathrm{S}(\mathrm{T})$ allele causes higher calcium levels (Jeong et al., 2016) and correlated to a decrease in calcium excretion in urine (Sonbol and Al Otaibi, 2016).

The CaSR is a coupled G-protein comprising three major components: a domain spanning seventransmembrane, an extracellular domain, and the intracellular domain (Alkukhun et al., 2017). It plays very important roles in calcium homeostasis in particular (Fahad et al., 2018) when there is a high concentration of extracellular calcium (Assimos, 2019). Also, it can induce phospholipases, ion transport, bicarbonate, acid transport, protein kinases activated by mitogen, and fluid secretion (Alkukhun et al., 2017). Calcium is an important cation that is contributed in several natural processes, for example, in bone formation, neurotransmission and muscle contraction (Toka et al., 2012). Approximately $99 \%$ of the calcium content of the body is found in the bones and teeth, the remaining $1 \%$ is in the bloodstream where it participates in the intracellular signals (Vinayagamoorthy et al., 2015). The body needs a large amount of calcium during growth, pregnancy and lactation. Thus, calcium deficiency has various effects on females from the fetus to the postmenopausal period, such as stunted growth and decreased bone density causing osteoporosis (Almaghamsi et al., 2018).

To the best of our knowledge, numerous studies have been carried out to estimate the relationship between CaSR gene polymorphism in the Caucasian healthy girls (Lorentzon et al., 2001), healthy Saudi adults of both sexes (Fahad et al., 2018), healthy postmenopausal (Young et al., 2003) and postmenopausal women from the Italian population with and without bone fragility (Cetani et al., 2003). However, there are no any study that included determination of CaSR gene polymorphism in premenopausal and postmenopausal women with osteoporosis. Therefore, the aim of this study was to determine the CaSR gene polymorphism A986S and evaluate its correlation with biochemical parameters in premenopausal and postmenopausal Iraqi women with osteoporosis in Salah Al-Din Province.

\section{Material and Methods}

\section{Study population}

In this study, 170 women aged 40-70 years volunteered from Salah al-Din Province. One hundred woman with osteoporosis (53 premenopausal and 47 postmenopausal) were diagnosed by specialist doctors in some private clinics and 70 healthy women as control group.

\section{Sample collection}

An aliquot of $5 \mathrm{ml}$ of blood samples were collected, of which $3 \mathrm{ml}$ was used to recover serum for calcium and phosphorus tests measured by spectrophotometric method using kits (Biomeurx Company, France). The remaining $2 \mathrm{ml}$ of blood samples were collected into EDTA tubes, stored at $-20{ }^{\circ} \mathrm{C}$ and used for DNA extraction as described by Ali et al. (2008).

PCR-RFLP analysis to determine polymorphism

CaSR gene polymorphism was determined using PCR-RFLP (polymerase chain reaction-restriction 
fragment length polymorphism) analysis. A 269 bp fragment of the CaSR gene was PCR-amplified according to the method reported by Dabiri et al. (2016). The forward primer sequence was 5'CTGAGCTTTGATGAGCCTCAGAAGGAC-3' and the reverse primer sequence was 5'CACTGATGACAAGCTCTGTGAACTGGA-3'.

The PCR was set up using the $2 \mathrm{X}$ Go Taq green master mix (Promega Company, USA) as follows: $4 \mu \mathrm{L}(100$ $\mathrm{ng}$ ) of genomic DNA, $1 \mu \mathrm{L}$ (10 picomole) of each primer, $10 \mu \mathrm{L}$ of master mix and $4 \mu \mathrm{L}$ of DNase/RNase free water in a total reaction volume of $20 \mu \mathrm{L}$. PCR cycling consisted of primary denaturation at $95^{\circ} \mathrm{C}$ for $5 \mathrm{~min}$, followed by 35 cycles of $95^{\circ} \mathrm{C}$ for $45 \mathrm{sec}, 63$ ${ }^{\circ} \mathrm{C}$ for $30 \mathrm{sec}$ and $72{ }^{\circ} \mathrm{C}$ for $45 \mathrm{sec}$. The reaction was concluded with one cycle of final extension at $72{ }^{\circ} \mathrm{C}$ for $5 \mathrm{~min}$. An aliquot of $5 \mu \mathrm{L}$ of the PCR product was digested with $10 \mathrm{U}$ of HinlI enzyme (New England, BioLabs, Inc.) at $37^{\circ} \mathrm{C}$ for 3 hours and visualized on $3.5 \%$ agarose gel electrophoresis containing red stain with the inclusion of 100 bp DNA ladder (BiolabsEngland).

\section{Statistical analysis}

Data were expressed as mean \pm standard deviation (SD). Statistical analysis was performed using SPSS version 20 PC program. One-way ANOVA and students' t-test were used for comparing means of biochemical parameters of the patient and control groups in relation to CaSR A986S genotypes. Allelic and genotypic frequencies, odds ratios (OR) and their $95 \%$ confidence intervals $(\mathrm{CI})$ of the patient and control groups were determined by utilizing Pearson's chi-square test. $\mathrm{P}$ value $(<0.05)$ was viewed as significant and $(<0.01)$ as highly significant.

\section{Results}

\section{Levels of calcium and phosphorus in the patient} and healthy control groups

The results of calcium and phosphorus levels in blood serum for 100 Iraqi women with osteoporosis and 70 healthy women control group are presented in Table 1 . The osteoporosis patients were further subdivided into two classes: premenopausal and postmenopausal women with osteoporosis. Serum calcium level in the control group was significantly higher $(10.5 \pm 1.38$ $\mathrm{mg} / \mathrm{dl}$ ) compared with the osteoporosis women group $(8.02 \pm 1.18 \mathrm{mg} / \mathrm{dl})$. Also, phosphorus level in the control group was significantly higher $(3.11 \pm 0.547$ $\mathrm{mg} / \mathrm{dl})$ than the patient group $(2.03 \pm 0.598 \mathrm{mg} / \mathrm{dl})$. There were no significant differences between calcium levels of premenopausal women $(8.00+1.16 \mathrm{mg} / \mathrm{dl})$ and postmenopausal women $(8.04+1.21 \mathrm{mg} / \mathrm{dl})$ with osteoporosis. More so, there was no significant difference between the levels of phosphorus of the premenopausal $(2.02+0.600 \quad \mathrm{mg} / \mathrm{dl})$ and postmenopausal $(2.05+0.601 \mathrm{mg} / \mathrm{dl})$ women with osteoporosis. Conversely, the results of the calcium and phosphorus parameters indicated a higher significance at ( $\mathrm{p}$-value <0.001) compared with the control and premenopausal women with osteoporosis or osteoporosis and control postmenopausal women.

Table-1. Comparison between calcium and phosphorus levels of the study groups

\begin{tabular}{|c|c|c|c|}
\hline \multicolumn{4}{|c|}{ Comparison between control and women with osteoporosis } \\
\hline \multirow{2}{*}{ Parameter } & \multicolumn{2}{|c|}{ Mean \pm SD } & \multirow{2}{*}{$p$ value } \\
\hline & Patients (100) & Control (70) & \\
\hline Calcium mg/dl & $8.02 \pm 1.18$ & $10.5 \pm 1.38$ & $0.001 * *$ \\
\hline Phosphorus mg/dl & $2.03 \pm 0.598$ & $3.11 \pm 0.547$ & $0.001 * *$ \\
\hline \multicolumn{4}{|c|}{ Comparison between premenopausal and postmenopausal women with osteoporosis } \\
\hline \multirow{2}{*}{ Parameter } & \multicolumn{2}{|c|}{ Mean \pm SD } & \multirow{2}{*}{$p$ value } \\
\hline & Premenopausal women $(53)$ & Postmenopausal women (47) & \\
\hline Calcium mg/dl & $8.00+1.16$ & $8.04+1.21$ & 0.88 \\
\hline Phosphorus mg/dl & $2.02+0.600$ & $2.05+0.601$ & 0.82 \\
\hline \multicolumn{4}{|c|}{ Comparison between control and premenopausal women with osteoporosis } \\
\hline \multirow{2}{*}{ Parameter } & \multicolumn{2}{|c|}{ Mean \pm SD } & \multirow{2}{*}{$p$ value } \\
\hline & Premenopausal women (53) & Control (70 & \\
\hline Calcium mg/dl & $8.00+1.16$ & $10.5+1.38$ & $0.001 * *$ \\
\hline Phosphorus mg/dl & $2.05+0.601$ & $3.11+0.547$ & $0.001 * *$ \\
\hline \multicolumn{4}{|c|}{ Comparison between control and postmenopausal women with osteoporosis } \\
\hline \multirow{2}{*}{ Parameter } & \multicolumn{2}{|c|}{ Mean \pm SD } & \multirow{2}{*}{$p$ value } \\
\hline & Postmenopausal women (47) & Control (70) & \\
\hline Calcium mg/dl & $8.04+1.21$ & $10.5+1.38$ & $0.001 * *$ \\
\hline Phosphorus mg/dl & $2.02+0.600$ & $3.11+0.547$ & $0.001 * *$ \\
\hline
\end{tabular}

$* \mathrm{p}<0.05$ significant and $* * \mathrm{p}<0.01$ highly significant. 
Polymorphic analysis revealed three genotypes of CaSR A986S gene

Analysis of PCR-RFLP products of the CaSR A986S gene revealed three genotypes: GG, GT and TT as revealed in Fig. 1. The frequency of alleles and genotypes is presented in Table 2 as a percentage (\%). There were highly important variances between the number and \% of genotypes and alleles of CaSR A986S polymorphism ( $\mathrm{p}$-value <0.01) compared with osteoporosis patients and control or premenopausal and postmenopausal osteoporosis groups with control. The percentage of osteoporosis women with TT genotype was $60 \%$ compared with $21.42 \%$ observed in the control group. On the contrary, GG genotype was $10 \%$ in the patient compared with $36 \%$ in the healthy groups. Our results also showed an increase in the odd ratio (OR) of the TT genotype (14.40) and T allele (5.571). On the other hands, there were no significant differences ( $p$-value 0.519) between premenopausal and postmenopausal women with osteoporosis.

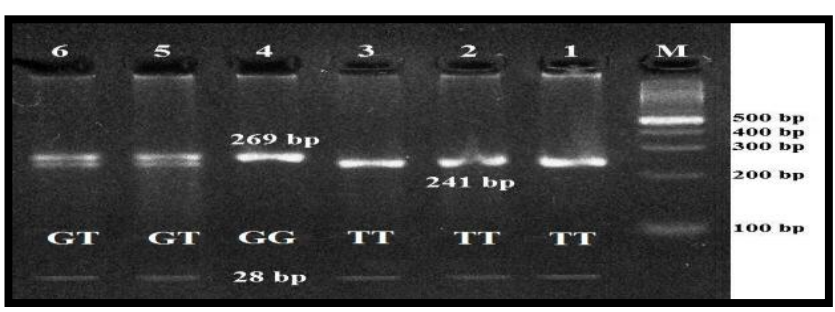

Figure-1. PCR-RFLP products of CaSR A986S genotypes fractionated on $3.5 \%$ agarose gel electrophoresis.

Lane M: 100 bp DNA ladder; Lanes 1-3: TT homozygote (241 and $28 \mathrm{bp}$ ); Lane 4: GG homozygote (269 bp); Lanes 4- 5: GT heterozygote (269, 241 and $28 \mathrm{bp})$.

Table-2. Number and percentage of genotypes and alleles of the CASR A986S polymorphism for the study groups

\begin{tabular}{|c|c|c|c|c|c|c|c|}
\hline \multicolumn{8}{|c|}{ Comparison between women with osteoporosis and control group } \\
\hline \multirow[b]{2}{*}{ Genotypes } & \multicolumn{2}{|c|}{ Patients (100) } & \multicolumn{2}{|c|}{ Control (70) } & \multirow{2}{*}{$p$ value } & \multirow[b]{2}{*}{ OR } & \multirow{2}{*}{$95 \%$ IC } \\
\hline & No. & $\%$ & No. & $\%$ & & & \\
\hline GG & 10 & 10 & 36 & 51.43 & \multirow{3}{*}{$<0.01 * *$} & 1 Ref. & - \\
\hline GT & 30 & 30 & 19 & 27.15 & & 5.684 & $2.296-14.067$ \\
\hline TT & 60 & 60 & 15 & 21.42 & & 14.40 & $5.851-35.438$ \\
\hline Allele Frequency & No. & $\%$ & No. & $\%$ & $p$ value & OR & $95 \%$ IC \\
\hline $\mathrm{G}$ & 50 & 25 & 91 & 65 & \multirow{2}{*}{$<0.01 * *$} & 1 Ref. & - \\
\hline $\mathrm{T}$ & 150 & 75 & 49 & 35 & & 5.571 & $3.474-8.934$ \\
\hline \multicolumn{8}{|c|}{ Comparison between premenopausal and postmenopausal women with osteoporosis } \\
\hline \multirow{2}{*}{ Genotypes } & Premeno & men (53) & & I women $(47)$ & . & $0 \mathbf{P}$ & $0=07$ IC \\
\hline & No. & $\%$ & No. & $\%$ & $p$ value & OR & $95 \% 1 \mathrm{C}$ \\
\hline GG & 4 & 24.5 & 6 & 23.4 & \multirow[b]{3}{*}{0.519} & 1 Ref. & - \\
\hline GT & 18 & 26.4 & 12 & 34.0 & & 2.250 & $0.522-9.697$ \\
\hline TT & 31 & 49.1 & 29 & 42.6 & & 1.603 & $0.410-6.264$ \\
\hline Allele Frequency & No. & $\%$ & No. & $\%$ & $p$ value & OR & $95 \%$ IC \\
\hline G & 26 & 24.5 & 24 & 25.5 & \multirow{2}{*}{0.870} & 1 Ref. & - \\
\hline $\mathrm{T}$ & 80 & 75.5 & 70 & 74.5 & & 1.054 & $0.555-2.002$ \\
\hline \multicolumn{8}{|c|}{ Comparison between premenopausal women with osteoporosis and control group } \\
\hline \multirow{2}{*}{ Genotypes } & Premeno & men (53) & & (70) & $n$ value & $\mathbf{O R}$ & $95 \%$ IC \\
\hline & No. & $\%$ & No. & $\%$ & $p$ value & OR & $95 \% \mathrm{IC}$ \\
\hline GG & 4 & 24.5 & 36 & 51.43 & \multirow{3}{*}{$<0.01 * *$} & 1 Ref. & - \\
\hline GT & 18 & 26.4 & 19 & 27.15 & & 8.526 & $2.523-28.813$ \\
\hline TT & 31 & 49.1 & 15 & 21.42 & & 18.600 & $5.585-61.937$ \\
\hline Allele Frequency & No. & $\%$ & No. & $\%$ & $p$ value & OR & $95 \%$ IC \\
\hline $\mathrm{G}$ & 26 & 24.5 & 91 & 65 & \multirow{2}{*}{$<0.01 * *$} & 1 Ref. & - \\
\hline $\mathrm{T}$ & 80 & 75.5 & 49 & 35 & & 5.714 & $3.256-10.028$ \\
\hline \multicolumn{8}{|c|}{ Comparison postmenopausal women with osteoporosis and control group } \\
\hline \multirow{2}{*}{ Genotypes } & Postmen & omen (47) & & (70) & $n$ value & OR & $95 \%$ IC \\
\hline & No. & $\%$ & No. & $\%$ & $p$ value & OR & $95 \% 1 \mathrm{C}$ \\
\hline GG & 6 & 24.5 & 36 & 51.43 & \multirow{3}{*}{$<0.01 * *$} & 1 Ref. & - \\
\hline GT & 12 & 26.4 & 19 & 27.15 & & 3.789 & $1.228-11.691$ \\
\hline TT & 29 & 49.1 & 15 & 21.42 & & 11.600 & $3.996-33.670$ \\
\hline Allele Frequency & No. & $\%$ & No. & $\%$ & $p$ value & $\mathbf{O R}$ & $95 \%$ IC \\
\hline $\mathrm{G}$ & 24 & 25.5 & 91 & 65 & \multirow[b]{2}{*}{$<0.01 * *$} & 1 Ref. & - \\
\hline $\mathrm{T}$ & 70 & 74.5 & 49 & 35 & & 5.416 & $3.035-9.667$ \\
\hline
\end{tabular}

$* \mathrm{p}<0.05$ significant and $* * \mathrm{p}<0.01$ high significant.

$\mathrm{OR}=$ odd ratio 
Effects of CaSR A986S polymorphism on calcium and phosphorus levels in study groups

The results of the effects of CaSR A986S polymorphism on calcium and phosphorus concentrations in osteoporosis women (Table 3) showed that there were no significant differences between all the CaSR A986S genotypes, although there were differences in the calcium levels. The phosphorus levels were highly significant (p-value 0.022 ) between the GG compared with GT genotypes. On the other hands, there was no significant difference between the calcium and phosphorus concentrations of the premenopausal and postmenopausal women with osteoporosis in relation to CaSR A986S polymorphism as depicted in Table 4.

Table-3. Effect of CaSR A986S polymorphism on biochemical parameters

\begin{tabular}{|l|l|l|l|}
\hline Parameter & GG (No. 10) & GT $($ No. 30) & P. value \\
\hline Calcium & $8.24 \pm 0.377$ & $7.68 \pm 0.696$ & 0.332 \\
\hline Phosphorus & $1.77 \pm 0.158$ & $2.25 \pm 0.147$ & $0.022^{*}$ \\
\hline Parameter & GG (No. 10) & TT $($ No. 60) & P. value \\
\hline Calcium & $8.24 \pm 0.377$ & $8.146 \pm 0.824$ & 0.727 \\
\hline Phosphorus & $1.77 \pm 0.158$ & $2.049 \pm 0.172$ & 0.15 \\
\hline Parameter & GT $($ No. 30) & TT $($ No. 60) & P. value \\
\hline Calcium & $7.68 \pm 0.696$ & $8.146 \pm 0.824$ & 0.091 \\
\hline Phosphorus & $2.25 \pm 0.147$ & $2.049 \pm 0.172$ & 0.765 \\
\hline
\end{tabular}

Table-4. Comparison between calcium and phosphorus levels of premenopausal and postmenopausal osteoporosis women in relation to CaSR A986S polymorphism

\begin{tabular}{|l|l|l|l|}
\hline \multirow{3}{*}{ Parameter } & $\begin{array}{l}\text { Premenopausal } \\
\text { women (53) }\end{array}$ & $\begin{array}{l}\text { Postmenopausal } \\
\text { women (47) }\end{array}$ & \multirow{2}{*}{ p value } \\
\cline { 2 - 3 } & GG No. 4 & GG No. 6 & \\
\hline Calcium & $8.1 \pm 0.483$ & $8.33 \pm 0.301$ & 0.368 \\
\hline Phosphorus & $1.87 \pm 0.282$ & $1.71 \pm 0.264$ & 0.762 \\
\hline Parameter & GT No. 18 & GT No. 12 & p value \\
\hline Calcium & $7.483 \pm 0.702$ & $7.975 \pm 0.592$ & 0.467 \\
\hline Phosphorus & $2 \pm 0.297$ & $2.183 \pm 0.175$ & 0.869 \\
\hline Parameter & TT No. 31 & TT No. 29 & p value \\
\hline Calcium & $8.280 \pm 0.105$ & $8.003 \pm 0.126$ & 0.195 \\
\hline Phosphorus & $2.063 \pm 0.128$ & $2.035 \pm 0.218$ & 0.836 \\
\hline
\end{tabular}

\section{Discussion}

Homeostasis of calcium plays a vital role in controlling bone makeup and alters the regulatory mechanisms that causes development of metabolic bone diseases (Cetani et al., 2003). This study showed a significant decrease in the concentration of serum calcium $(8.02 \pm 1.18)$ and phosphorus $(2.03 \pm 0.598)$ of the women with osteoporosis compared with the control group. These observations are consistent with the studies of Shakoor et al. (2014) and Li et al. (2020) and inconsistent with other studies (Hamdi, 2013; Ali, 2018). The concentrations of serum calcium and phosphate can vary according to physiological, biochemical and pathological variations (Ikechukwu et al., 2005). Although, phosphorus levels showed a significant variance between the osteoporosis (2.03 $\pm 0.598)$ and control $(3.11 \pm 0.547)$ groups, while serum phosphorus concentration was still within a normal range. This result agrees with previously published work which revealed that there was no noticeable differences in the analysis of osteoporosis (Omrani et al., 2006; Mutlu et al., 2007). Meanwhile, there was no significant difference in the calcium and phosphorus levels between premenopausal and postmenopausal women with osteoporosis. These results support the finding of Pandey et al. (2013). This observation may be due to the calcium hemostasis which is regulated by multifactor, like parathyroid hormone, vitamin D, and dietary intake (Martins et al., 2017; Wasilewski et al., 2019).

Recent study on genetic SNPs in osteoporosis will continue to be interesting and useful because of the potential impact of race and ethnic factors (Haryono et al., 2019). Some mutations and SNPs of CaSR gene are related to many benign diseases, so, detection of the genotyping of CaSR gene will help in assessing susceptibility to osteoporosis in adults and patients (Sonbol and Al Otaibi, 2016). Some researchers investigated the association between osteoporosis and SNP of some genes, but there has been no report on the comparison between CaSR A986S polymorphism of premenopausal and postmenopausal women with osteoporosis. We investigated the CaSR A986S polymorphism among Iraqi women with osteoporosis in premenopausal and postmenopausal status. The frequency of T mutant allele (75\%) of the CaSR gene was higher than the $\mathrm{G}$ wildtype allele $(25 \%)$ of the osteoporosis patient compared with the frequency of $\mathrm{T}$ mutant allele $(35 \%)$ and the wildtype allele A $(65 \%)$ in the control. No significant difference was observed in the CaSR A986S genotypes, although there were differences in the number and percentage between premenopausal and postmenopausal women with osteoporosis. The number of patients was relatively small and in addition to the differences in the genetic family history that altered the results of the association. Researches have shown that not only multiple genetic factors are responsible, but also environmental factors affect osteoporosis disease 
(Fahad et al., 2018). As a result of the role of CaSR in bone and mineral metabolism, many genetic studies have been achieved to explore its effect on bone mass variability. A few of these studies are in agreement with our results and indicated that CaSR gene can affect bone mineral density variations. An example of such study is the work of Wang et al. (2006) that found a significant correlation between the CaSR and bone mineral density in the Chinese population. Another study was on the Japanese postmenopausal women which revealed a significant relationship between the CaSR polymorphism and bone mineral density (Tsukamoto et al., 2000). In a study on the Jewish Israelites, CaSR heterozygote polymorphism, A986S was associated with lower bone mineral density in premenopausal women (Eckstein et al., 2002). Meanwhile, the findings obtained from some studies were different as in Mo et al. (2004) who found no important relationship between CaSR A986S polymorphism and bone mineral density in premenopausal women. Also, there was no significant difference in the bone mineral density in a study on 164 Italian postmenopausal women CaSR A986S polymorphism (Cetani et al., 2003). More so, from the study of 113 Saudi adults from both sexes, it was concluded that there was no clinical importance in the CaSR genotype on bone mineral density (Fahad et al., 2018).

We tested the possibility of CaSR A986S polymorphism being linked to biochemical concentrations, but found that the mutant $\mathrm{T}$ allele in osteoporosis women was not linked with increased levels of circulating calcium. Although, the TT genotype of the osteoporosis women had higher levels of serum calcium $(8.146 \pm 0.824)$ than osteoporosis women with GT genotype $(7.68 \pm 0.696)$. There was a difference in the calcium levels between the GG and GT genotypes but the difference was non-significant. This was because of the small number of women with GG genotype (ten persons) which represented $5 \%$ of all the patients, that could be related to participant's lifestyle and environment (Al-Azzawie et al., 2019). Thus, there was an indication of a biological effect of the $\mathrm{S}$ allele depending on calcium results between $\mathrm{GG}$, GT, and TT genotypes as shown in Table 1 and 3 . These results are in agreement with a study by Lorentzon et al. (2001) which was carried out on 97 Caucasian healthy girls and they found that the subjects with $\mathrm{S}$ allele had high levels of calcium. Another study indicated that the CaSR A986S polymorphism might be correlated with calcium levels in the healthy subjects of the Chinese population (He et al., 2012). The small number of patients (100) in our study may be the reason for the insignificant differences between women with osteoporosis. Reports have shown that differences in calcium levels were detected by the CaSR which conserved calcium levels, but led to decreasing mineral content of the bone (Di Nisio et al., 2018). This observation could also be attributed to the homeostasis of serum calcium and phosphorus which were affected by many factors. These factors include specific organ interactions, mainly the skeleton, kidneys and intestines. Also, hormones such as calcitonin and parathyroid hormone, vitamin $\mathrm{D}$ have also been reported to help preserve homeostasis of the mineral calcium and phosphorus (Berndt et al., 2005; Allen and Burr, 2014).

\section{Conclusion}

The results from this study revealed that A986S polymorphism of CaSR is one of the genetic susceptibility factors for the premenopausal and postmenopausal Iraqi women with osteoporosis and it had non-significant effects on mineral levels. Therefore, further studies involving a large number of people in different provinces of Iraq are required in order to confirm our findings.

\section{Acknowledgement}

The authors express their gratitude to the members of Central Research Laboratory, University of Tikrit, Tikrit, Iraq for providing laboratory materials and equipment for carrying out this study.

\section{Disclaimer: None. \\ Conflict of Interest: None. Source of Funding: None.}

\section{References}

Al-Azzawie AF, Al-sugmiany RZ and Salih NA, 2019. Cholesteryl ester transfer protein Taq1B gene polymorphism in some Iraqi patients with lipid disorders. Eurasian J. Biosci. 13(1): 253-258.

Al-Azzawie AF, Husain WN, Salih MH and AL-Assie $\mathrm{AH}$, 2020. The relationship between some electrolyte levels and MTHFR C667T gene polymorphism in premenopausal and postmenopausal oste oporosis Iraqi 
women. Eurasian J. Biosci. 14(1): 545-551.

Ali NK, 2018. Estimation of some mineral (calcium, phosphorous, vitamin $25(\mathrm{OH}) \mathrm{D}$ and alkaline phosphatase) in osteoporosis patients in Kirkuk city. J. Osteopor. Phys. Act. 6(2). DOI: 10.4172/2329-9509.1000215.

Ali SM, Mahnaz S and Mahmood T, 2008. Rapid genomic DNA extraction (RGDE). Forensic Sci. Int. Genet. Suppl. Ser.1(1): 63-65.

Alkukhun A, Munoz-Abraham AS, Judeeba S and Geibel JP, 2017. Molecular Aspects of the Calcium-Sensing Receptor and Calcium Homeostasis, 15-26. In Molecular, Genetic, and Nutritional Aspects of Major and Trace Minerals. Academic Press.

DOI: https://doi.org/10.1016/C2014-0-02224-1.

Allen MR and Burr DB, 2014. Bone modeling and remodeling. In Basic and applied bone biology 7590. Academic Press. DOI: https://doi.org/10.1016/C2011-0-05817-9.

Almaghamsi A, Almalki MH and Buhary BM, 2018. Hypocalcemia in pregnancy: A clinical review update. Oman Med. J. 33(6): 453.

Assimos DG, 2019. Re: Novel Mutations Associated with Inherited Human Calcium-Sensing Receptor Disorders: A Clinical Genetic Study. J. Urol. 202(1): 26-26.

Berndt TJ, Schiavi S and Kumar R, 2005. Phosphatonins and the regulation of phosphorus homeostasis.

Am.

J.

Physiol. Renal. Physiol. 289(6): 1170-1182.

Boroňová IBJ, Kl’oc J, Tomková Z, Petrejčíková E, Mačeková S and Blaščáková MM, 2014. Analysis of OPG Gene Polymorphism T245G (rs3134069) in Slovak Postmenopausal Women. Analysis. 2: 12859.

Cetani F, Pardi E, Borsari S, Vignali E, Dipollina G, Braga VBA, Adami S, Pinchera A and Marcocci C, 2003. Calcium-sensing receptor gene polymorphism is not associated with bone mineral density in Italian postmenopausal women. Eur. J. Endocrinol. 148(6): 603-608.

Dabiri R, Mahmoudi T, Farahani H, Nobakht H and Zali MR, 2016. Alanine to serine variant at position 986 of calcium sensing receptor and colorectal cancer risk. Iran J. Cancer Prev. 9(4): e8098. doi: 10.17795/ijcp-8098.

Di Nisio A, Santa Rocca M, Ghezzi M, Ponce MDR, Taglianetti S, Plebani M, Ferlin A and Foresta C, 2018. Calcium-sensing receptor polymorphisms increase the risk of osteoporosis in ageing males. Endocrine. 61(2): 349-352.

Eckstein M, Vered I, Ish-Shalom S, Shlomo AB, Shtriker A, Koren-Morag $\mathrm{N}$ and Friedman E, 2002. Vitamin D and calcium-sensing receptor genotypes in men and premenopausal women with low bone mineral density. IMAJ-RAMAT GAN. 4(5): 340-344.

Fahad W, Otaibi A and Sonbol HS, 2018. CalciumSensing Receptor Gene Polymorphisms among Saudi Adults: The Possible Relation with Calcium and Bone Mineral Density. Middle East J. Appl. Sci. 8(2): 382-389.

Hamdi RA, 2013. Evaluation of Serum Osteocalcin level in Iraqi Postmenopausal women with primary osteoporosis. J. Fac. Med. Baghdad. 55(2):166-169.

Haryono IR, Tulaar A, Sudoyo H, Purba A, Abdullah M, Jusman SW, Lubis AMT and Ilyas EI, 2019. Polymorphisms within RANKL and Osteoprotegerin Genes in Low Bone Mass among Postmenopausal Indonesian Women. Turk Osteoporoz Dergisi. 25(1): 28.

He Y, Han L, Li W, Shu X, Zhao C, He Y, Bi M, Li Y and Sun C, 2012. Effects of the calcium-sensing receptor A986S polymorphism on serum calcium and parathyroid hormone levels in healthy individuals: a meta-analysis. Gene. 491(2): 110115.

Hosseinpanah F, Daneshpour MS, Ahmadi N, Behnami SP and Azizi F, 2014. Vitamin D Receptor Gene Polymorphism and Bone Mineral Density in Iranian Menopausal and Postmenopausal Women. Scimetr. 2(4). DOI: 10.5812/scimetr.18167.

Ikechukwu IC, AO UC, Uzoma IC, Hughs MAT and Ekenedirichukwu OJ, 2005. Does Pregnancy actually affect serum calcium and inorganic phosphate levels?. Shiraz E. Med. J. 6(1): 31836.

Jeong S, Kim JH, Kim MG, Han N, Kim IW, Kim T and Oh JM, 2016. Genetic polymorphisms of CASR and cancer risk: evidence from metaanalysis and HuGE review. OncoTargets Therap. 9: 655-669.

Kanwar G, Jain N, Kirad S, Yadav M and Rathore SP, 2014. A study on Serum lipid profile in hypertensive patients of Hadoti region. IMPACT: IJRANSS. 2(8): 53-60.

Li GHY, Robinson-Cohen C, Sahni S, Au PCM, Tan KCB, Kung AWC and Cheung CL, 2020. Association of Genetic Variants Related to Serum Calcium Levels with Reduced Bone Mineral 
Density. J Clin. Endocrinol. Metab. 105(3): dgz088.

Lorentzon M, Lorentzon R, Lerner UH and Nordstrom $\mathrm{P}$, 2001. Calcium sensing receptor gene polymorphism, circulating calcium concentrations and bone mineral density in healthy adolescent girls. Eur. J. Endocrinol. 144(3): 257-261.

Majid H, Khan AH and Moatter T, 2015. R990G polymorphism of calcium sensing receptor gene is associated with high parathyroid hormone levels in subjects with vitamin D deficiency: a crosssectional study. BioMed. Res. Int. 2015: 407159. doi: $10.1155 / 2015 / 407159$.

Martins JS, Palhares MDO, Teixeira OCM and Ramos MG, 2017. Vitamin D status and its association with parathyroid hormone concentration in Brazilians. J Clin Nutr Metab. 2017. https://doi.org/10.1155/2017/9056470.

Masvidal L, Iniesta R, García M, Casalà C, Lavarino C, Mora J and de Torres C, 2017. Genetic variants in the promoter region of the calcium sensing receptor gene are associated with its down regulation in neuroblastic tumors. Mol. Carcinogen. 56(4): 1281-1289.

Mo XY, Zhang YY, Lei SF and Deng HW, 2004. A986S polymorphism of calcium-sensing receptor gene is not related to bone mineral density or bone size in premenopausal Chinese women. Di Yi Jun Yi Da Xue Xue Bao = Academic journal of the first medical college of PLA. 24(10): 1097-101.

Mondockova V, Adamkovicova M, Lukacova M, Grosskopf B, Babosova R, Galbavy D, Martiniakova M and Omelka R, 2018. The estrogen receptor 1 gene affects bone mineral density and osteoporosis treatment efficiency in Slovak postmenopausal women. BMC Med. Genomics. 19(1): 174.

Moura KF, Haidar M, Bonduki C, Feldner Junior PC, Silva I, Soares Junior JM and Girao MJ, 2014. Frequência do polimorfismo da interleucina-6, GST, e dos receptores de progesterona em mulheres na pós-menopausa com baixa densidade mineral óssea. Sao Paulo Med. J. 132(1): 36-40.

Mutlu M, Argun M, Kilic ESER, Saraymen R and Yazar S, 2007. Magnesium, zinc and copper status in osteoporotic, osteopenic and normal postmenopausal women. J. Int. Med. Res. 35(5): 692695.

Omrani GR, Masoompour SM, Sadegholvaad A and Larijani B, 2006. Effect of menopause and renal function on vitamin D status in Iranian women. East. Mediter. Health J. 12 (1-2): 188195, 2006.

Pandey SK, Singh A, Polipalli SK, Gupta S and Kapoor S, 2013. Association of Methylene Tetrahydrofolate Reductase Polymorphism with BMD and Homocysteine in Premenopausal North Indian Women. JCDR. 7(12): 2908.

Pouresmaeili F, Kamalidehghan B, Kamarehei M and Goh YM, 2018. A comprehensive overview on osteoporosis and its risk factors. Therapeut. Clin. Risk Manage. 14: 2029-2049.

Rasmussen AQ, Jørgensen NR and Schwarz P, 2018. Identification and functional characterization of a novel mutation in the human calcium-sensing receptor that co-segregates with autosomaldominant hypocalcemia. Front. Endocrinol. 9: 110 .

Sassi R, Sahli H, Souissi C, Sellami S and Ben Ammar El Gaaied A, 2015. Polymorphisms in VDR gene in Tunisian postmenopausal women are associated with osteopenia phenotype. Climacteric. 18(4): 624-630.

Shakoor S, Ilyas F, Abbas N, Mirza MA and Arif S, 2014. Prevalence of osteoporosis in relation to serum calcium and phosphorus in aging women. $\mathrm{J}$. Glob. Innov. Agric. Soc. Sci. 2(2): 70-75.

Sonbol HS and Al Otaibi WF, 2016. Genotype and Allele Frequencies of Calcium-Sensing Receptor Gene a986s (rs1801725) Polymorphism in Saudi Adults. J. Genet. Disor. Genet. Rep. 5(3): doi:10.4172/2327-5790.1000141.

Tang Q, Zhao Y, Wang Y and Wei M, 2014. A genetic variant (rs17251221) in the calcium-sensing receptor relates to hepatocellular carcinoma susceptibility and clinical outcome treated by transcatheter hepatic arterial chemoembolization (TACE) therapy. Med. Oncol. 31(11): 267.

Toka HR, Al-Romaih K, Koshy JM, DiBartolo S, Kos CH, Quinn SJ, Curhan GC, Mount DB, Brown EM and Pollak MR, 2012. Deficiency of the calcium-sensing receptor in the kidney causes parathyroid hormone-independent hypocalciuria. J. Am. Soc. Nephrol. 23(11): 18791890.

Tsukamoto K, Orimo H, Hosoi T, Miyao M, Ota N, Nakajima T, Yoshida H, Watanabe S, Suzuki T and Emi M, 2000. Association of bone mineral density with polymorphism of the human calciumsensing receptor locus. Calcif. Tissue Int. 66(3): 181-183. 
Vinayagamoorthy N, Yim SH, Jung SH, Park SW, Kim YJ, Kim BJ and Chung YJ, 2015. Association of common variants in the calcium-sensing receptor gene with serum calcium levels in East Asians. J. Hum. Genet. 60(8): 407-412.

Wasilewski GB, Vervloet MG and Schurgers LJ, 2019. The Bone-Vasculature Axis: Calcium Supplementation and the Role of Vitamin K. Front. Cardiovasc. Med. 6: 6.

Yan S, Yuan C, Yang Q, Li X, Yang N, Liu X, Dong R, Zhang X, Yuan Z, Zhang N and Kong B, 2015. A genetic polymorphism (rs17251221) in the calcium-sensing receptor is associated with ovarian cancer susceptibility. Oncol. Rep. 34(4): 2151-2155.
Wang YB, Guo JJ, Liu YJ, Deng FY, Jiang DK and Deng HW, 2006. The human calcium-sensing receptor and interleukin- 6 genes are associated with bone mineral density in Chinese. Acta Genetica Sinica. 33(10): 870-880.

Young R, Wu F, Van de Water N, Ames R, Gamble G and Reid IR, 2003. Calcium sensing receptor gene A986S polymorphism and responsiveness to calcium supplementation in postmenopausal women. J. Clin. Endocrinol. Metab. 88(2): 697700 .

Zhu Y, Chen J, Cheng H and Cai W, 2017. Estrogen receptor alpha gene polymorphisms contribute to fragility fracture susceptibility in elderly postmenopausal women with heart failure. Int. J. Clin. Exp. Med. 10(2): 3435-3444. 